\title{
Optimal selection and placement of BMPs and LID practices with a rainfall-runoff model
}

\author{
Yaoze Liu ${ }^{\mathrm{a}}$; Raj Cibin ${ }^{\mathrm{a}}$; Vincent F. Bralts ${ }^{\mathrm{a}}$; Indrajeet Chaubey ${ }^{\mathrm{a}, \mathrm{b}}$; Laura C. Bowling ${ }^{\mathrm{c}}$; Bernard A. Engel ${ }^{\mathrm{a}}$ \\ ${ }^{a}$ Department of Agricultural and Biological Engineering, Purdue University, West Lafayette, IN 47907, USA \\ ${ }^{\mathrm{b}}$ Department of Earth, Atmospheric and Planetary Sciences, Purdue University, West Lafayette, IN 47907, USA \\ ${ }^{\mathrm{c}}$ Department of Agronomy, Purdue University, West Lafayette, IN 47907, USA
}

Corresponding author: Bernard A. Engel, Department of Agricultural and Biological Engineering, Purdue University, 225 South University Street, West Lafayette, IN 47907-2093, USA. E-mail address: engelb@purdue.edu, Phone number: 1-765-494-1162

\begin{abstract}
A decision support tool, which links a hydrologic/water quality model (L-THIA-LID 2.1) with optimization algorithms (AMALGAM) using a computational efficiency framework (MLSOPT), was developed to optimally implement BMPs and LID practices to reduce runoff and pollutant loads. The decision support tool was applied in the Crooked Creek watershed, Indiana, USA. For initial expenditures on practices, the environmental benefits increased rapidly as expenditures increased. However, beyond certain expenditure levels, additional spending did not result in noticeable additional environmental impacts. Compared to random placement of practices, the optimization strategy provided 3.9 to 7.7 times the level of runoff/pollutant load reductions for the same expenditures. To obtain the same environmental benefits, costs of random practices placement were 4.2 to 14.5 times the optimized practice placement cost. The decision support tool is capable of supporting decision makers in optimally selecting and placing BMPs and LID practices to obtain maximum environmental benefits with minimum costs.
\end{abstract}

\section{Keywords:}

Optimization; runoff; water quality; cost; best management practices; low impact development practices. 


\section{Introduction}

Best management practices (BMPs) and low impact development (LID) practices are two effective measures used to reduce the adverse impacts of urbanization on hydrology and water quality. BMPs and LID practices can treat and control runoff and pollutants generated by stormwater. In comparison to BMPs (such as wetland basins and retention ponds), which are large scale treatment facilities with big drainage areas, LID practices (such as green roof and rain barrel/cistern) are localized measures that treat stormwater runoff close to the source with relatively small drainage areas (Prince George's County, 1999; The LIDC et al., 2006; Dietz, 2007; USEPA, 2008; Gilroy, 2009; Damodaram et al., 2010).

The planning strategies for implementing BMPs and LID practices at watershed scales incorporate conflicts among environmental concerns and economic considerations. The possible types, locations, and percentages at which to apply BMPs/LID practices at a watershed scale are numerous because of the complexity of land uses, soil properties, and site characteristics of the watershed. Therefore, it is not feasible to identify the performances of all potential combinations of BMP and LID practice scenarios at watershed scales. The conflict among environmental considerations and economic concerns make it complex to solve the problem. For example, implementing additional practices in a given area would likely have increased environmental benefits; however, the cost to construct and maintain BMPs and LID practices would increase at the same time. Since watershed management projects usually have limited budgets or an explicit environmental impact goal, an efficient systematic approach is needed for decision makers to optimally select and place BMPs and LID practices by comparing tradeoffs among environmental impacts and economic considerations.

To obtain maximum environmental benefits at minimum cost, spatial optimization has become a popular multi-objective method that has tradeoff solutions to select and place BMPs and LID practices at watershed scales (e.g. Gitau et al., 2004; Maringanti et al., 2009, 2011; McGarity, 2012, 2013a, 2013b; Rodriguez et al., 2011; Lee et al., 
2012; Lautenbach et al., 2013). Spatial optimization solves optimization problems by combining simulation models with optimization algorithms. The optimization algorithms generate sample populations of possible placement scenarios, while the hydrology/water quality model computes the objective functions with the sample populations created to obtain optimal results. However, most spatial optimization methods require significant computational time to complete the model simulations due to the complexity of optimization problems (Arabi et al., 2006). Pseudo-simulation models, which contain lookup tables, can be used to reduce computational burden (Gitau et al., 2004; Maringanti et al., 2009, 2011; Sudheer et al., 2011). However, this approach typically reduces the accuracy of results from the original simulation model and creates another level of uncertainty. Parallel computing is another popular approach used to reduce simulation time (Rao, 2005; Rouholahnejad et al., 2012; Joseph and Guillaume, 2013; Yalew et al., 2013; Liu et al., 2014).

Using parallel computing, the multilevel spatial optimization (MLSOPT) framework (Cibin and Chaubey, 2015), which has two optimization levels (sub-area level and watershed level) that can be completed in sequence, was developed to reduce computational complexity of optimization with hydrologic models. The MLSOPT framework was found to have good performance in optimal front convergence and computing time at watershed scales (Cibin and Chaubey, 2015). The selection of optimization algorithms is vital in spatial optimization to ensure convergence of the objective functions. Single or multi-optimization algorithms can be run repeatedly to compare results and find the best solution. A Multi-ALgorithm Genetically Adaptive Multiobjective (AMALGAM) method (Vrugt and Robinson, 2007) is a multi-algorithm method found to be more efficient than single algorithm methods (Zhang et al., 2010, 2013; Cibin and Chaubey, 2015). AMALGAM uses self-adaptive offspring creation to combine the strengths of multiple optimization algorithms (Vrugt and Robinson, 2007).

The Long-Term Hydrologic Impact Assessment-Low Impact Development 2.1 (L-THIA-LID 2.1) model was created to evaluate the impacts of BMPs and LID 
practices on hydrology and water quality at watershed scales with the ability to estimate total expenditures on practices (Liu et al., 2015b), but optimal selection and placement of practices considering environmental and economic concerns using the model has not been studied. The MLSOPT framework and AMALGAM were combined to optimize stover removal rates with minimum environmental influences (Cibin and Chaubey, 2015), but they have never been combined to optimally select and place BMPs and LID practices. A decision support tool, which can help decision makers determine the most cost efficient implementations of BMPs and LID practices in reducing runoff volume and pollutant loads by linking the L-THIA-LID 2.1 model with AMALGAM using the MLSOPT framework needs to be explored. While other researchers have optimized the selection and placement of a small number of practices (e.g. Gitau et al., 2004; Maringanti et al., 2009, 2011; Rodriguez et al., 2011; Lautenbach et al., 2013), the implementation of the following group of BMPs/LID practices, including permeable patio, grassed swale, green roof, bioretention system, rain barrel, cistern, porous pavement, grass strip, wetland channel, wetland basin, retention pond, and detention basin, has not been optimized at watershed scales in urban areas.

The objectives of this study were to: (1) develop a decision support tool to optimally select and place BMPs and LID practices by linking the L-THIA-LID 2.1 model with AMALGAM using the MLSOPT framework; (2) demonstrate the use of the tool to optimize hydrologic response unit (HRU) scale and watershed scale implementation of BMPs and LID practices; and (3) compare optimization results with the findings of random BMP and LID practice implementation scenarios in the same watershed.

\section{Development of a decision support tool}

To find the best selection and placement of BMPs and LID practices with tradeoffs among costs and environmental benefits, a decision support tool was developed by linking the L-THIA-LID 2.1 model with AMALGAM (Vrugt and Robinson, 2007) using the MLSOPT framework (Cibin and Chaubey, 2015). The 
development of the decision support tool is described in the following sections.

\subsection{Simulation model-L-THIA-LID 2.1 model}

The L-THIA-LID 2.1 model (Liu et al., 2015b) was developed from the L-THIA-LID 2.0 model (Liu et al., 2015a) to simulate the impacts of BMPs and LID practices on hydrology and water quality at watershed scales. As in previous versions of L-THIA models that have been applied in various studies (e.g. Harbor, 1994; Bhaduri et al., 1997; Pandey et al., 2000; Engel et al., 2003; Tang et al., 2005; Choi, 2007; Davis et al., 2010; Ahiablame et al., 2012, 2013), with daily rainfall data, hydrologic soil group data, and land use data, the L-THIA-LID 2.1 model estimates runoff volume using the curve number method and computes pollutant loads by multiplying runoff volume with pollutant concentration from each specific land use.

Currently, there are nine LID practices (permeable patio, grassed swale, green roof, bioretention system, rain barrel, cistern, porous pavement, grass strip, and wetland channel) and three BMPs (wetland basin, retention pond, and detention basin) represented in the L-THIA-LID 2.1 model (Liu et al., 2015a, 2015b). Using data from the International Stormwater Best Management Practices (BMP) Database (www.bmpdatabase.org), the impacts of BMPs and LID practices on runoff volume are calculated using curve number $(\mathrm{CN})$ and percent runoff reduction methods. The influence of BMPs and LID practices on pollutant loads is estimated using runoff volume reduction, irreducible concentration, and pollutant concentration reduction methods (Liu et al., 2015a). Curve number values of LID practices can be found in Ahiablame et al. (2012), and see Liu et al. (2015a) for percent runoff reduction values. Irreducible concentration and ratio of outflow concentration to inflow concentration values are shown in Tables A.1 and A.2, respectively, in the appendix.

The model simulates BMPs and LID practices starting at the hydrologic response unit (HRU) scale. HRUs are areas with the same land uses and hydrologic soil groups. Based on the site characteristics and other logistical concerns, such as drainage area, drainage slope, imperviousness, hydrologic soil group, road buffer, stream buffer, and building buffer, suitable locations to implement BMPs and LID practices are selected. The suitable practices are combined with HRUs to generate the unique combinations 
of suitable BMPs/LID practices and HRUs. The drainage areas of LID practices and BMPs are based on the characteristics of the practices; for example, porous pavement/patio treats runoff from the surface of pavement/patio; grass swale, grass strip, and wetland channel treat runoff from the same unique combinations of BMPs/LID practices and HRUs; and BMPs treat runoff from one or more HRUs that may include some runoff treated by LID practices. For details of drainage areas of practices, please refer to Liu et al. (2015b). Depending on the features of the practices, some LID practices can be implemented in series with each other in the same HRU; LID practices can be in series with BMPs; and BMPs are independent of each other, meaning they cannot be in series. The L-THIA-LID 2.1 model can also estimate the total cost to implement BMPs and LID practices, which makes it possible to consider economics in the optimization problem. The total cost considered in the model includes construction cost, maintenance cost, and opportunity cost. More detailed information on the L-THIA-LID 2.1 model can be obtained from Liu et al. (2015a, 2015b).

\section{$\underline{\text { 2.2 Multilevel spatial optimization (MLSOPT) framework and optimization }}$}

\section{algorithms (AMALGAM)}

The MLSOPT framework (Cibin and Chaubey, 2015) contains two levels to reduce the computational complexity of optimization problems. The first level divides the watershed into smaller areas, and the optimization for each area is conducted individually. A lookup table of optimal results of objective functions is created for the first level single sub-areas. By satisfying the objective functions at the watershed scale, the second level conducts watershed scale optimization by linking optimization algorithms with the lookup table created based on the results of the first level. With one model run, the L-THIA-LID 2.1 model can provide results of objective functions for all sub-areas, which enables parallel computing in the first level optimization. For more details on the MLSOPT framework, readers should consult Cibin and Chaubey (2015).

To obtain faster and more dependable results for multi-objective optimization problems, AMALGAM combines the strengths of multiple optimization algorithms 
by running different algorithms at the same time using self-adaptive offspring creation (Vrugt and Robinson, 2007). The method adapts search procedures that adapt population sizes from optimization algorithms based on their performances in the guiding search to obtain well distributed Pareto-optimal front solutions. The fast non-dominated sorting algorithm (Deb et al., 2002) is used by AMALGAM for population ranking. There are four mutually consistent and complementary evolutionary optimization algorithms in the default AMALGAM (Vrugt and Robinson, 2007), including differential evolution (DE) (Storn and Price, 1997), adaptive metropolis search (AMS) (Haario et al., 2001), particle swarm optimization (PSO) (Kennedy and Eberhart, 2001), and Non-dominated Sorted Genetic Algorithm II (NSGAII) (Deb et al., 2002). Matlab source code for AMALGAM can be found at http://faculty.sites.uci.edu/jasper/sample.

\subsection{Decision support tool theory}

\subsubsection{Decision support tool schematic}

The schematic of the decision support tool is shown in Figure 1. The L-THIA-LID 2.1 model is used to quantify the environmental impacts and costs of implementing BMPs/LID practices. Proposed BMPs include wetland basin, retention pond, and detention basin; and proposed LID practices include permeable patio, grassed swale, green roof, bioretention system, rain barrel, cistern, porous pavement, grass strip, and wetland channel. The L-THIA-LID 2.1 model divides the watershed into hydrologic response units (HRUs), which have the same land use types and hydrologic soil groups. When simulating LID practices, HRUs are in parallel and assumed not to affect each other. By definition, LID practices are localized techniques that make this assumption valid. A portion of runoff and NPS pollutants treated by LID practices can be treated by BMPs. This means that after runoff and pollutant loads are treated by LID practices, a portion of the remaining runoff and pollutants can be treated by BMPs. This portion represents the percentage of suitable locations with BMPs implemented. Possible BMP and LID practice options for each HRU are identified based on site characteristics and other logistical concerns, such as drainage area, drainage slope, imperviousness, hydrologic soil group, road buffer, stream buffer, and 
building buffer (Liu et al., 2015b). Unique combinations of HRUs and suitable BMPs/LID practices are created, and referred to as sub-areas. Runoff and pollutants are routed from HRUs to the watershed outlet by additive routing, which means that values are simply added together.

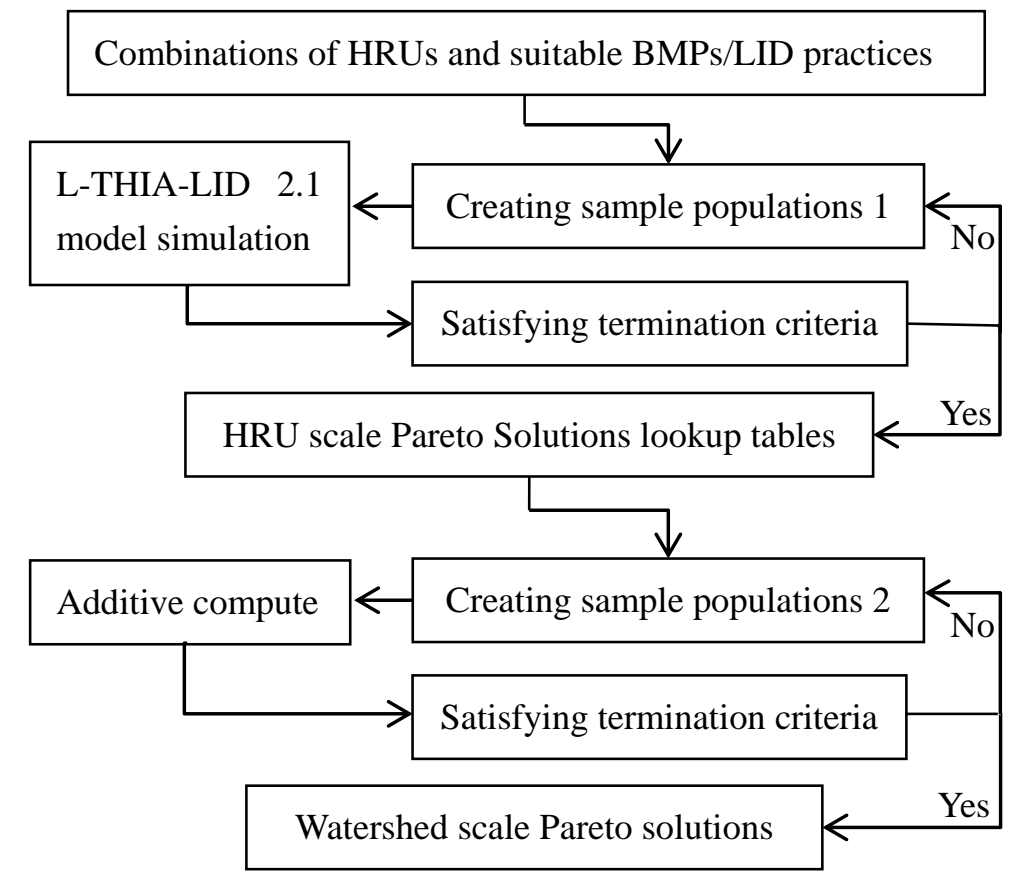

Figure 1. Schematic of decision making tool to optimally select and place BMPs and LID practices. Sample populations 1 are various percentages of BMP and LID practice implementation in each sub-area (e.g. a combination of $1 \%$ green roof and $4 \%$ wetland basin). Sample populations 2 are various combinations of first level Pareto solutions.

In the first level optimization, sample populations 1, which are various percentages of suitable BMP and LID practice implementation in each sub-area, are created by AMALGAM until termination criteria are satisfied. Termination criteria of AMALGAM were set with population sizes and generation sizes. Generation size is one of the parameters in AMALGAM, setting how many generations are created. Each generation has a number of populations. Sample populations are inputs for the L-THIA-LID 2.1 model. After model simulations are completed for all sample populations, lookup tables are created with optimum results for implementing practices in all sub-areas. The sub-areas, which are HRU scale areas, are the unique combinations of HRUs and suitable BMPs/LID practices. 
The second level optimization is conducted at the watershed level based on the optimum results for the sub-area level. Since all optimization scenarios in this tool only consider the impacts of BMPs and LID practices at the source level, the best solutions in each sub-area of the first level are used to estimate watershed level objective functions using an additive approach. Sample populations 2, which are various combinations of first level Pareto solutions, are created by picking one Pareto solution from each sub-area using AMALGAM until satisfying the termination criteria. The corresponding results of objective functions from each sub-area are added together to obtain watershed scale Pareto solutions.

\subsubsection{Optimization scenarios}

The optimal selection and placement of BMPs and LID practices requires consideration of the suitability of locations to implement practices, the percentages of suitable locations with BMPs/LID practices implemented, the environmental impacts of practices, and the cost of applying practices.

Multi-objective optimization can compute multiple objective functions with tradeoff solutions to maximize the positive impacts on environment (hydrology and water quality) and minimize the cost of implementing BMPs and LID practices. The decision support tool conducts multi-objective optimization using two objective functions because of the complicated multi-dimensional decision vector generated by scenarios of more than two objective functions. For example, the results of using two objective functions can be plotted with a 2-dimensional coordinate system, which is easy to explain. However, the results of using three or more objective functions needs to be plotted using multi-dimensional coordinate systems, which greatly increases the complexity of explanations.

In this study, the objective function (Equation 1) was defined to: (1) minimize the cumulative runoff/pollutant value (CRPV), which is a fraction or multiple fractions that can exceed 1 when added together and thus can exceed $100 \%$ when expressed as a percentage (Equations 2 to 7), generated from a watershed after implementing BMPs/LID practices, and (2) minimize the cost of implementing BMPs/LID practices. The numerators of fractions in CRPV are runoff volume or pollutant loads after 
implementing BMPs/LID practices, and the corresponding denominators are runoff volume or pollutant loads before implementing practices. Dimensionless fractions are used in this study because it is a common approach used in optimal selection and placement of BMPs and LID practices (Gitau et al., 2004; Maringanti et al., 2011). Constraints are considered in the optimization problem to identify suitable locations to implement practices. The entire area of the watershed is the potential area to implement practices, and the percentages of suitable locations with BMPs/LID practices implemented are the variables used to search for optimal solutions.

Objective function $=\min (C R P V \wedge C o s t)$

\section{Constraints:}

Constraints of suitable locations to implement BMPs/LID practices from Liu et al. (2015b) include drainage area, drainage slope, imperviousness, hydrologic soil group, road buffer, stream buffer, and building buffer.

\section{Variables:}

Percentages of suitable locations with BMPs/LID practices implemented. Numerators are sizes of areas chosen to implement BMPs/LID practices, and denominators are size of areas suitable for implementing BMPs/LID practices.

In the decision support tool, six optimization scenarios are created with tradeoffs to minimize runoff volume (RV) (Scenario 1, Eq. 2), minimize sediment loads (TSS) (Scenario 2, Eq. 3), minimize nutrient loads (TP, TN) (Scenario 3, Eq. 4), minimize metal loads (Pb) (Scenario 4, Eq. 5), minimize organic compounds (BOD and COD) (Scenario 5, Eq. 6), and minimize all pollutant amounts mentioned above (Scenario 6, Eq. 7).

$$
\begin{aligned}
& \text { Runoff_CRPV }=\frac{\text { Runoff }}{\text { Runoff }}, \\
& \text { Sediment_CRPV }=\frac{T S S}{T S S^{\prime}} \\
& \text { Nutrient_CRPV }=\frac{T P}{T P^{\prime}}+\frac{T N}{T N^{\prime}} \\
& \text { Metal_CRPV }=\frac{P b}{P b^{\prime}}
\end{aligned}
$$


Organic_Compounds_CRPV $=\frac{B O D}{B O D^{\prime}}+\frac{C O D}{C O D^{\prime}}$

$A l l \_p o l l u t a n t s \_C R P V=\frac{T S S}{T S S^{\prime}}+\frac{T P}{T P^{\prime}}+\frac{T N}{T N^{\prime}}+\frac{P b}{P b^{\prime}}+\frac{B O D}{B O D^{\prime}}+\frac{C O D}{C O D^{\prime}}$

Where, runoff and pollutant names are the runoff volume and pollutant loads, respectively, after implementing BMPs and LID practices. runoff' and pollutant names' are the runoff volume and pollutant loads, respectively, before implementing BMPs and LID practices.

Although in the default decision support tool, the constraints are the criteria of suitable locations to implement BMPs/LID practices, it is possible to add other potential constraints, such as budget limitations. All pollutant loads are given equal weights in these optimization scenarios. If the reduction of a certain pollutant load is more or less important, the weights can be changed. Additional optimization scenarios can be added to combine other groups of pollutants that may be of interest for a particular site. Instead of minimizing runoff volume and pollutant loads at the outlet of the watershed, all of these scenarios consider the reductions at the HRU level, and minimize average runoff volume and pollutant loads from all HRUs. In the current implementation, there would be no difference between optimization for all HRUs and for the watershed outlet, because there are no routing losses in the current L-THIA-LID model.

\section{Case study}

The decision support tool was applied to optimize hydrologic response unit (HRU) scale and watershed scale implementation of BMPs and LID practices in an urbanized watershed. Optimization results were compared with the findings of random BMP and LID practice implementation scenarios in the same watershed. The study area and methods of the case study are described in the following sections.

\subsection{Study area}

The study area was Crooked Creek watershed, which is a highly urbanized watershed in central Indiana, USA with a 5,129 ha drainage area. The locations of 
Crooked Creek Watershed and hydrologic response units (HRUs) are shown in Figure

2. The characteristics of HRUs in the watershed are shown in Table 1. The watershed, which has about $72.04 \%$ low density (LD) residential area, 6.92\% high density (HD) residential area, $6.12 \%$ commercial area, and $2.63 \%$ industrial area, is an urban watershed. The current water quality threats to the watershed, as reported in the Upper White River Watershed Regional Watershed Assessment and Planning Report (Tedesco et al., 2011), include Total Nitrogen (TN), Total Phosphorus (TP), Total Suspended Solids (TSS), Lead (Pb), Biochemical Oxygen Demand (BOD), and Chemical Oxygen Demand (COD).

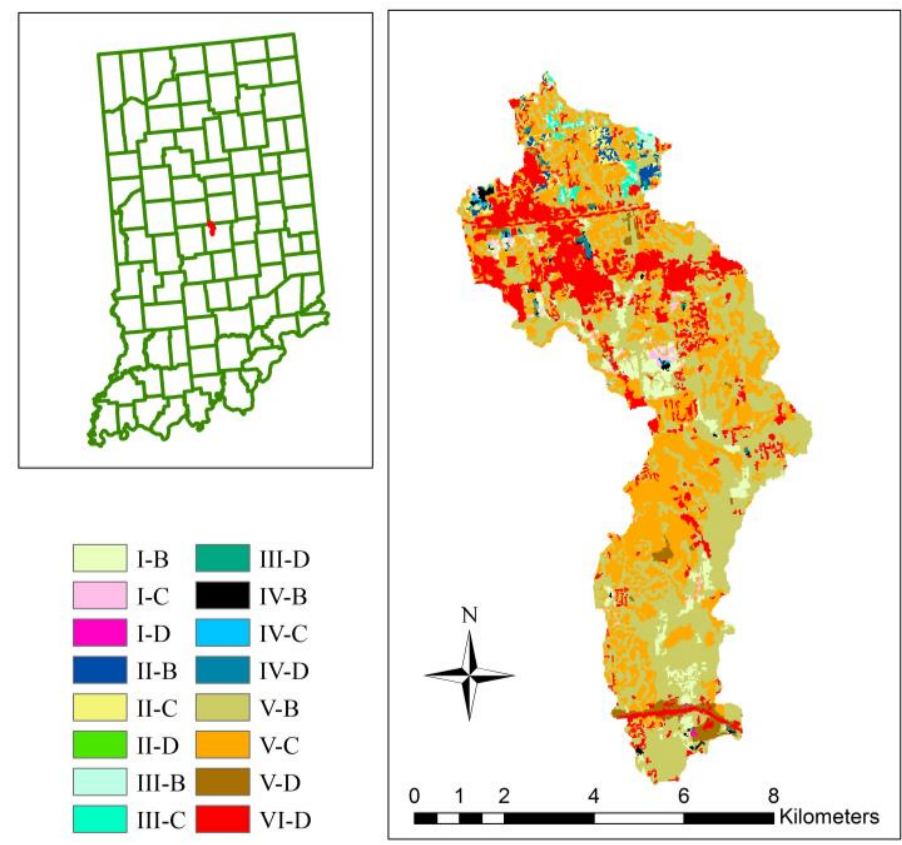

Figure 2. Locations of Crooked Creek Watershed and HRUs. I, II, III, IV, V, and VI are Forest/Woods, Agricultural, Grass/Pasture, Water/Wetland, LD residential, and HD residential/Industrial/Commercial land uses, respectively. B, C, and D are hydrologic soil groups $B, C$, and $D$, respectively.

Table 1. Characteristics of HRUs

\begin{tabular}{llll}
\hline Land use & Hydrological Soil group & Area (ha) & Code \\
\hline \multirow{3}{*}{ Forest/Woods } & B & 257.4 & I-B \\
& C & 53.7 & I-C \\
\hline
\end{tabular}




\begin{tabular}{llll}
\hline & D & 3.9 & I-D \\
Agricultural & B & 81.3 & II-B \\
& C & 74.1 & II-C \\
& D & 0.7 & II-D \\
Grass/Pasture & B & 50.2 & III-B \\
& C & 51.4 & III-C \\
& D & 0.4 & III-D \\
Water/Wetland & B & 28.5 & IV-B \\
& C & 12.2 & IV-C \\
& D & 16.4 & IV-D \\
LD residential & B & 2045.1 & V-B \\
& C & 1550.6 & V-C \\
\hline
\end{tabular}

\subsection{Decision support tool application}

The calibrated and validated L-THIA-LID 2.1 model from Liu et al. (2015b), which studied the same watershed from 1993 to 2010, was used in this study. The optimal selection and placement of practices started from the current watershed condition with only retention ponds implemented in the watershed. BMPs and LID practices considered in this study with their unique integer codes are shown in Table 2. Design life of all BMPs/LID practices was assumed as 20 years, and the interest rate was $4.5 \%$ when computing total cost. The costs and performances of BMPs/LID practices used in this example may not necessarily represent expenditures and effectiveness of practices for other locations, and values should be adjusted to reflect local conditions. The percentages and types of BMPs and LID practices implemented in the suitable area were optimized using the decision support tool. The performance of AMALGAM in the decision support tool was improved by changing population 
size and number of generations, while other parameters of the optimization algorithms in AMALGAM were set as recommended (Vrugt and Robinson, 2007).

Table 2. BMPs and LID practices considered in this study

\begin{tabular}{lll}
\hline Categories of practices & Names of practices & Integer Codes \\
\hline \multirow{3}{*}{ BMPs } & Retention pond & 1 \\
& Detention basin & 2 \\
& Wetland basin & 3 \\
& Rain Barrel/Cistern & 4 \\
& Permeable patio & 5 \\
& Green Roof & 6 \\
& Grassed Swale & 7 \\
LID practices & Grass strip & 8 \\
& Wetland Channel & 9 \\
& Bioretention system & 10 \\
& Porous Pavement & 11 \\
\hline
\end{tabular}

\subsection{Random scenario evaluation}

The calibrated and validated L-THIA-LID 2.1 model from Liu et al. (2015b) was also used in this portion of the study. Two random BMP and LID practice implementation scenarios, in which practices were randomly applied to suitable areas, were compared with the optimization results. One way was to compare environmental benefits of the optimized and random strategies for the same budget. The other way was to compare the total cost of optimization and random scenarios with the same environmental impacts.

The random scenarios were developed starting from specifying suitable areas, which were unique combinations of HRUs and suitable BMPs/LID practices. Then, the implementation percentages of practices were randomly assigned from a group of preset values. Specific locations of the practices cannot be selected, such as a specific parking lot or an exact roof top, since implementation percentages of practices were 
based on percentages of suitable areas (unique combinations of HRUs and suitable BMPs/LID practices). For example, instead of implementing green roofs on exact roof tops in a certain suitable area, $1 \%$ of roof tops in the suitable area were implemented with green roofs. In actual implementation, BMPs/LID practices would be selected by individual land owners and the modeling approach captures this by assigning a percentage of BMPs/LID practices to suitable areas. The random scenarios, which were applied starting from the current situation with only retention ponds implemented (Liu et al., 2015b), included: Random Scenario 1 (RS1) with a combination of $1 \%$ green roof, $2.5 \%$ rain barrel/cistern, $0.5 \%$ green roof with rain barrel/cistern, $2.5 \%$ bioretention system, $1 \%$ porous pavement, $1 \%$ permeable patio, $2.5 \%$ grass strip, $2.5 \%$ grassed swale, $2.5 \%$ wetland channel, $2.5 \%$ retention pond, $2.5 \%$ detention basin, and 2.5\% wetland basin; and Random Scenario 2 (RS2) with a combination of $1 \% \mathrm{rain}$ barrel/cistern, $1 \%$ bioretention system, $0.5 \%$ porous pavement, $0.5 \%$ permeable patio, $1 \%$ grass strip, $1 \%$ grassed swale, $1 \%$ wetland channel, $1 \%$ retention pond, $1 \%$ detention basin, and $1 \%$ wetland basin.

Based on costs or environmental impacts of random scenarios, the corresponding optimization scenarios were created by obtaining the optimized scenarios during the optimization process with the same costs or environmental benefits. For instance, for a random scenario with a given expenditure, the corresponding optimization simulation with the same cost was found; based on a random scenario's environmental impact, the corresponding optimization simulation with the same environmental impact was obtained.

\section{Results and Discussion}

The decision support tool was applied in the Crooked Creek watershed to optimally select and place BMPs and LID practices. For the specific application of the decision support tool, population sizes and number of generations were changed to find the most suitable parameters in AMALGAM. Based on the results of changing population sizes and number of generations, sizes of the population and generation 
used in the first level MLSOPT optimization were 100 and 400, respectively, for all optimization scenarios; in the second level MLSOPT optimization, all optimization scenarios were calculated using population size of 100 and generation size of 10000 .

The first level optimizations were finished on Intel Xeon-E5 processors with 12 parallel Matlab workers, which took about 5.25 days for each scenario. The second level optimizations were completed on a $3.40 \mathrm{GHz}$ Intel Core i7-3770 CPU with 1 Matlab worker, which took about 4 hours for each scenario.

\subsection{Possible locations of BMPs and LID practices}

All BMPs selected in the study were assumed to be suitable in all areas in the watershed due to the fact that stormwater runoff from any HRU can be directed to any of the selected BMPs with pipes and channels. In this study, 123 unique combinations of HRUs and suitable BMPs/LID practices were created. When HRUs are ignored, 17 possible combinations of suitable LID practices were found. Possible locations of the selected LID practices in Crooked Creek watershed were identified as shown in Figure 3. The combinations of numbers shown in Figure 3 were the unique combinations of LID practices that were suitable to be implemented in that area. Over $41 \%$ of the total area was suitable only to implement BMPs, including retention pond, detention basin, and wetland basin. About $14 \%$ of the whole watershed was suitable for BMPs and porous pavement. Approximately $11 \%$ of the study area was suitable to implement BMPs, grassed swale, grass strip, wetland channel, bioretention system, and porous pavement. The rest of the watershed was suitable for other combinations of BMPs and LID practices. The optimal implementation of BMPs and LID practices at HRU and watershed scales were analyzed, and the results are discussed in the following sections. 


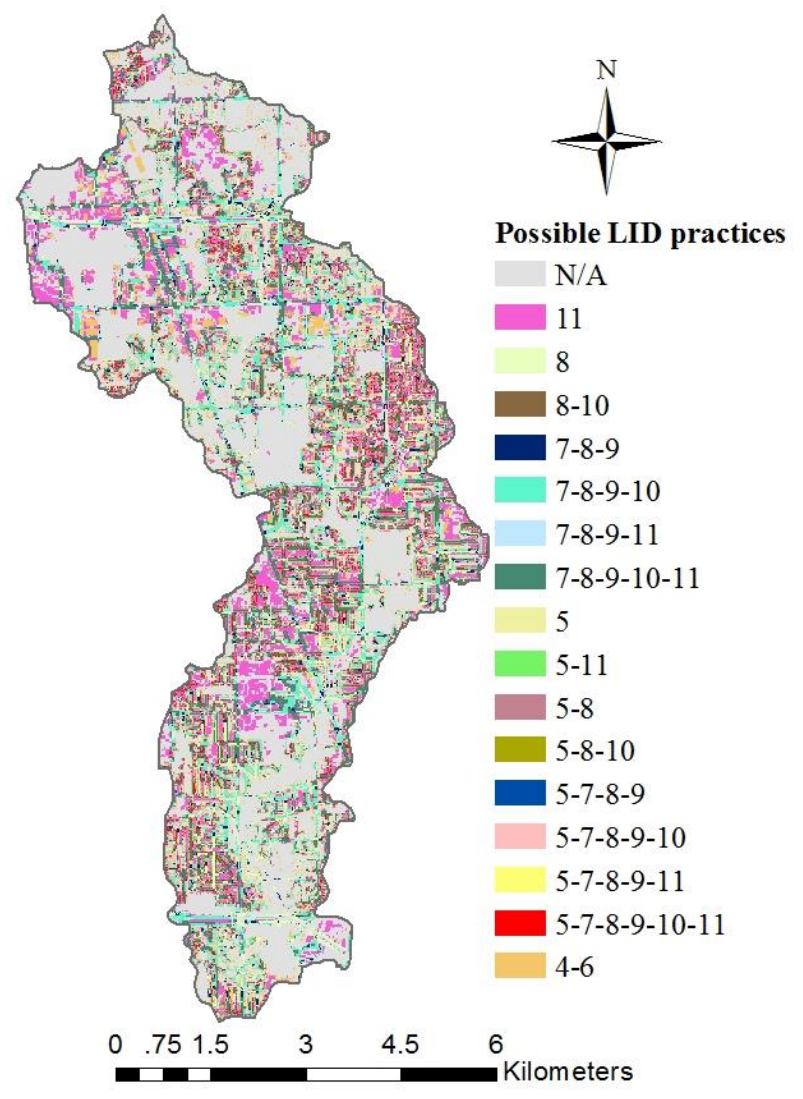

Figure 3. Possible locations of LID practices in Crooked Creek watershed

\section{$\underline{4.2}$ HRU scale optimization results}

Figure 4 shows four examples of HRU scale optimization results for four sub-areas with objective functions to minimize runoff volume (Fig 4a-c) and minimize TSS load (Fig 4d) at minimum cost. In Figure 4, dark grey circles are Pareto solutions; $\mathrm{X}$-axis and $\mathrm{Y}$-axis shows the costs to implement BMPs/LID practices and corresponding target percent runoff volume or TSS load reductions, respectively. Figure 4 represents the required combinations of BMPs/LID practices for a target volume or TSS reduction. Detailed Pareto solutions for various percentages of implementing BMPs and LID practices in the selected HRU areas to reduce runoff volume or TSS loads are shown in Figure 5. Table 3 shows annual cost per unit of runoff volume/pollutant load reduction for suitable BMPs and LID practices corresponding to sub-areas selected in Figure 4. Lower annual cost per unit of runoff volume/pollutant load reduction indicates a higher cost efficiency of the BMP/LID practice in reducing runoff volume/pollutant load. 
Table 3. Annual cost per unit of runoff volume/pollutant load reduction for suitable BMPs and LID practices corresponding to sub-areas selected in Figure 4

\begin{tabular}{lllll}
\hline \multirow{2}{*}{ Names of practices } & \multicolumn{2}{l}{ Annual cost per unit runoff volume } & Annual cost per TSS load \\
& reduction $\left(\$ / \mathrm{m}^{3} / \mathrm{yr}\right)$ & reduction $(\$ / \mathrm{kg} / \mathrm{yr})$ \\
\cline { 2 - 5 } & Fig.3(a) & Fig.3(b) & Fig.3(c) & Fig.3(d) \\
\hline Retention pond & 14.6 & 20.8 & 21.1 & 75.7 \\
Detention basin & 3.6 & 5.1 & 5.2 & 80.5 \\
Wetland basin & 26.0 & 37.0 & 37.4 & 73.0 \\
Grassed Swale & 2.1 & 3.0 & 3.0 & 45.0 \\
Grass strip & 0.8 & 1.1 & 1.1 & 14.2 \\
Wetland Channel & N/A & N/A & N/A & 102.1 \\
Bioretention system & 14.9 & 21.1 & 21.4 & 480.5 \\
Porous Pavement & 16.8 & 15.4 & 16.4 & 465.6 \\
Porous Pavement+ & 18.4 & 18.8 & 19.9 & 531.3 \\
Bioretention system & & & & \\
\hline
\end{tabular}

The selected area in Figure 4(a), with an area of 55 ha, was high density residential land use with hydrologic soil group $\mathrm{D}$, which was suitable for implementing retention pond, detention basin, wetland basin, grassed swale, grass strip, wetland channel, bioretention system, and porous pavement. Figure 4(a) indicates the maximum potential runoff volume reduction in this selected HRU scale area was $90 \%$ with the cost of 29 million dollars for a period of 20 years. Figure 5(a) shows that to reduce runoff volume in the selected HRU scale area, grass strip was the only favorable practice until a level of approximately $34 \%$ runoff volume reduction. At that level of reduction, grass strip implementation reached $100 \%$, requiring implementation of other practices for further reductions. In this particular case, grassed swale implementation increased from that point, and remained at $100 \%$ implementation after runoff volume reduction reached $62 \%$. Then, detention basin became favorable, and remained at $100 \%$ implementation after runoff volume 
reduction reached $77 \%$. Bioretention systems became favorable until reaching a level of $81 \%$ reduction of runoff volume. At $81 \%$ runoff volume reduction, porous pavement became favorable. Once the percentage of implementing porous pavement reached $100 \%$, bioretention system became favorable again. Wetland basin and wetland channel were not favorable during the whole search process because they were not as cost efficient as the favorable practices (as shown in Table 3). Although retention pond $\left(14.6 \$ / \mathrm{m}^{3} / \mathrm{yr}\right)$ was more cost efficient than bioretention system and porous pavement (Table 3), retention pond did not become favorable because it was assumed that BMPs are independent of each other and with $100 \%$ implementation percentage of detention basin, no other BMPs could be implemented in the same sub-area.

The selected areas in Figure 4(b) and Figure 4(c), with areas of 232 ha and 11 ha, respectively, were low density residential land use with hydrologic soil group C and industrial land use with hydrologic soil group $\mathrm{D}$, respectively. These areas were suitable for the same BMPs and LID practices as in Figure 4(a), including retention pond, detention basin, wetland basin, grassed swale, grass strip, wetland channel, bioretention system, and porous pavement. Figure 4(b) shows the maximum potential runoff volume reduction in the selected HRU scale area was $91 \%$ by spending 95 million dollars over a period of 20 years. Figure 4(c) shows the potential of reducing runoff volume by $87 \%$ in the selected HRU area with a cost of 4.4 million dollars for a period of 20 years. Figures 5(b) and 5(c) show similar behavior for changes of favorable BMPs and LID practices compared to Figure 5(a), except that bioretention system was not favorable during any of the search process for the HRU with results presented in Figure 5(b), and biorentention system only became favorable following high percentages of porous pavement implementation as depicted in Figure 5(c).

The differences among the optimal solutions to reduce runoff volume by implementing BMPs/LID practices were due to different features of the HRUs. In the selected area of Figure 5(a), because of the land uses and soil properties, the cost per unit runoff volume reduction (Table 3) of bioretention system $\left(14.9 \$ / \mathrm{m}^{3} / \mathrm{yr}\right.$ ) was slightly lower than that of porous pavement $\left(16.8 \$ / \mathrm{m}^{3} / \mathrm{yr}\right)$. Therefore, bioretention 
system was favorable first. When implementation of bioretention systems reached $100 \%$ (all areas that can be treated with bioretention are treated), further reduction of runoff volume resulted in implementation percentage of bioretention systems decreasing. The cost-effectiveness of practices was in the order of bioretention system alone>porous pavement alone> porous pavement and bioretention systems combined (Table 3). Implementing porous pavement alone had the potential to reduce runoff volume more than implementing bioretention systems alone. Thus, when the implementation percentage of bioretention systems reached $100 \%$, porous pavement replaced bioretention systems, because the combination of porous pavement and bioretention system was not as cost-effective as porous pavement alone, and implementing porous pavement alone could attain the runoff volume reduction required. After the implementation percentage of porous pavement reached and remained at $100 \%$, bioretention system became favorable again to further reduce runoff volume. If the decision support system implementation assumptions, costs and performances of the practices such as bioretention system and porous pavement changed, the relationships of cost-efficiencies may change. In such as case, the optimized results will change, and the decision support tool would need to be rerun to obtain updated optimization results.

For the selected areas in 4(b) and 4(c), the cost per unit runoff volume reduction of porous pavement (15.4\$ $\$ \mathrm{~m}^{3} / \mathrm{yr}$ and $16.4 \$ / \mathrm{m}^{3} / \mathrm{yr}$, respectively) was lower than that of bioretention system $\left(21.1 \$ / \mathrm{m}^{3} / \mathrm{yr}\right.$ and $21.4 \$ / \mathrm{m}^{3} / \mathrm{yr}$, respectively) because of land use and soil type features; as a result, porous pavement became favorable first.

In Figure 5(a) and 5(c), when bioretention system became favorable at about 90\% reduction of runoff volume, the percentage of implementing porous pavement remained high; this is because implementing only bioretention system was unable to reduce runoff volume more than $100 \%$ implementation of porous pavement did, leading to the need to implement both practices.

The selected area in Figure 4(d) was the same as in Figure 4(a). Figure 4(d) shows the potential of reducing TSS by $96 \%$ at a cost of 27 million dollars for a period of 20 years. Figure 5(d) shows similar changes of favorable BMPs and LID practices as in 
Figure 5(a), except that at $84 \%$ reduction in TSS loads, instead of detention basin, wetland basin became favorable for the area associated with Figure 5(d). This was because wetland basin $(73.0 \mathrm{\$} / \mathrm{kg} / \mathrm{yr}$ ) was more favorable in reducing TSS than reducing runoff volume compared to detention basin $(80.5 \$ / \mathrm{kg} / \mathrm{yr})$. Although wetland channel (102.1 \$/kg/yr), retention pond (75.7 \$/kg/yr), and detention basin $(80.5$ $\$ / \mathrm{kg} / \mathrm{yr}$ ) were more cost efficient than some of the favorable practices (Table 3), they did not become favorable because it was assumed that BMPs are independent of each other and wetland channel is independent of grassed swale; with $100 \%$ implementation percentage of wetland basin, no other BMPs could be implemented for the same sub-area; with $100 \%$ implementation percentage of grassed swale, wetland channel could not be implemented for the same sub-area. The occasional relative high percentages of detention basin and bioretention system for the area associated with Figure 5(d) were because there were various ways to reduce TSS at the same cost. This indicates that for the same combination of HRU and suitable BMPs/LID practices, favorable percentages and combinations of BMPs and LID practices could vary for different environmental goals.

The change points of favorable BMPs and LID practices depicted in Figure 5 correspond to the sharp turning points of Pareto fronts in Figure 4. The sharp turning points of Pareto fronts occurred when new BMPs/LID practices became favorable. This was expected because with different favorable BMPs and LID practices in the same HRU, the abilities of BMPs/LID practices to reduce runoff volume/pollutant loads were different for the same cost. Note that optimal selection and placement of BMPs and LID practices was based on tradeoffs of cost and runoff volume/pollutant load reduction. This meant that the higher priority of selecting and placing a BMP/LID practice during optimization was due to the lower cost per unit runoff volume/pollutant load reduction. In Figure 4, the piecewise linear behaviors of the Pareto solutions were due to the characteristics of the L-THIA-LID 2.1 model, which is a lumped parameter model that represents BMPs/LID practices using the curve number method, percent runoff reduction method, irreducible concentration method, 
and percent pollutant concentration reduction method. If a more complicated simulation model was used, the Pareto solutions would be expected to be nonlinear.

Figure 5 shows that with the increase of runoff volume/TSS reductions (consistent with cost increments in Figure 4), most types of the BMPs/LID practices selected in the Pareto solutions were already selected with lower implementation percentages for lower expenditures; the types of favored practices increased with expenditure. These features in Figure 5 demonstrated the need to optimally select and place BMPs and LID practices that give higher priorities to practices with lower cost in reducing per unit runoff volume/pollutant load.

For presentation purposes, four examples of optimization results for unique combinations of HRUs and suitable BMPs/LID practices, and only runoff volume reduction and TSS reduction were presented. The study examined all 123 combinations of HRUs and suitable BMPs/LID practices, and for runoff volume/various pollutant yields. Similar results could be plotted for runoff volume/pollutants yields for any combinations of HRUs and suitable BMPs/LID practices.

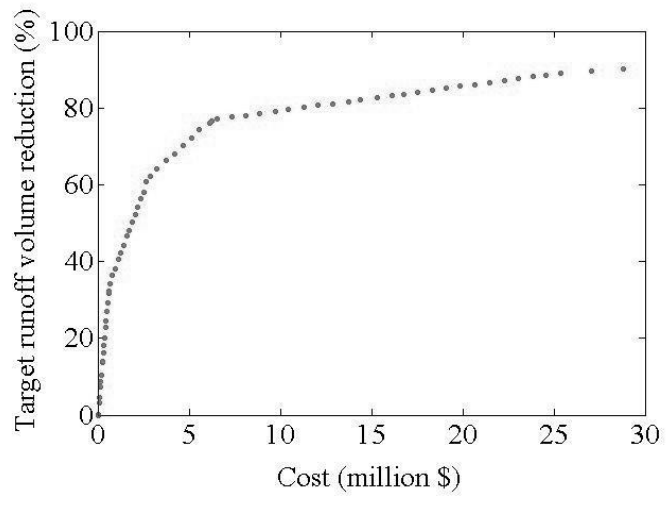

(a) High density residential with soil group D

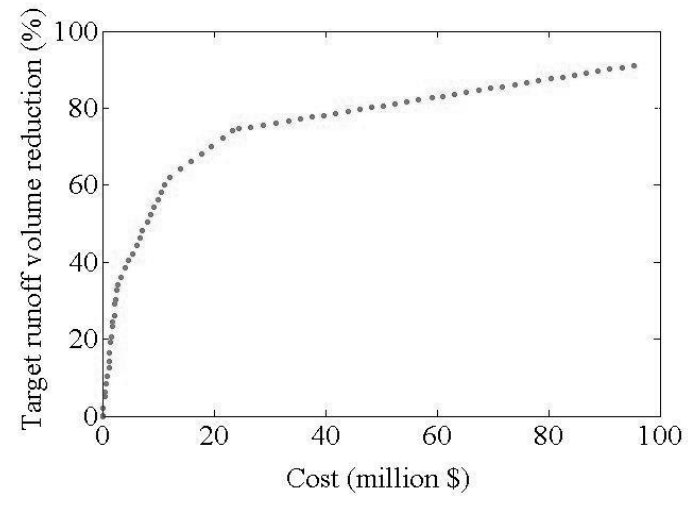

(b) Low density residential with soil group $\mathrm{C}$ 


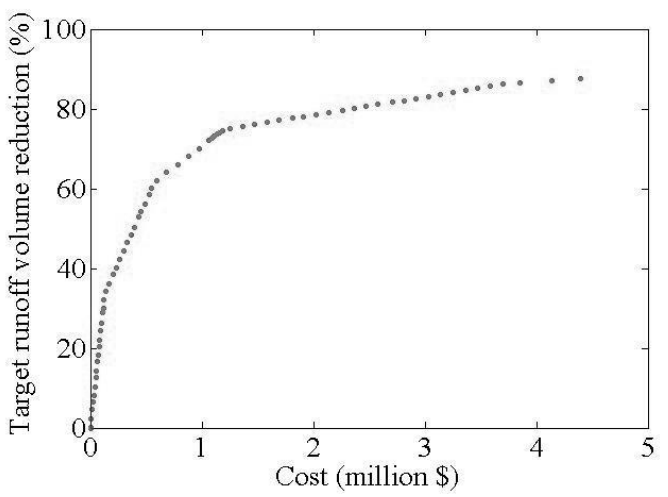

(c) Industrial with soil group D

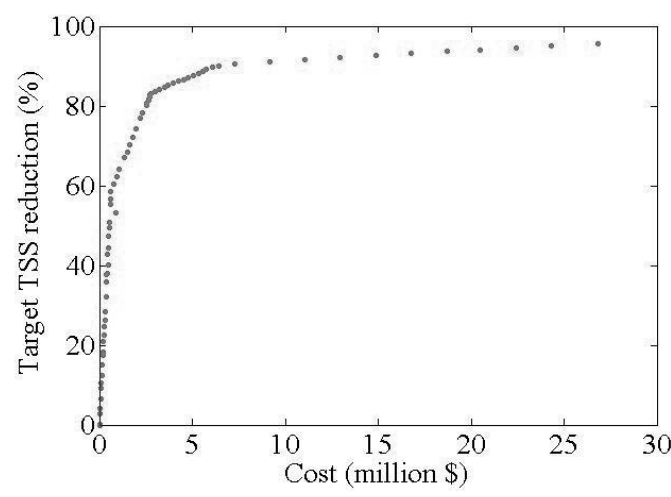

(d) High density residential with soil group D

Figure 4. Examples of optimization results for HRU scale areas, which were suitable for

retention pond, detention basin, wetland basin, grassed swale, grass strip, wetland channel, bioretention system, and porous pavement. Costs presented were totals for 20 years. Selected areas were 55 ha, 232 ha, 11 ha, and 55 ha, respectively. Runoff volume reduction and TSS reduction were target reductions.

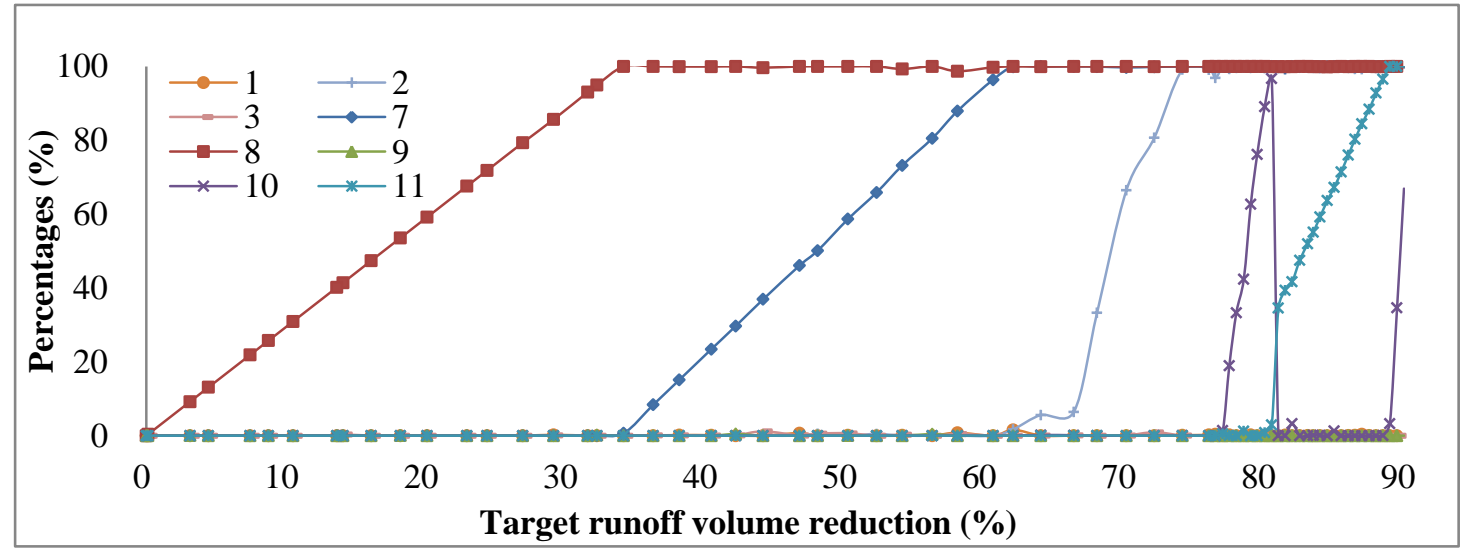

(a) High density residential with soil group D

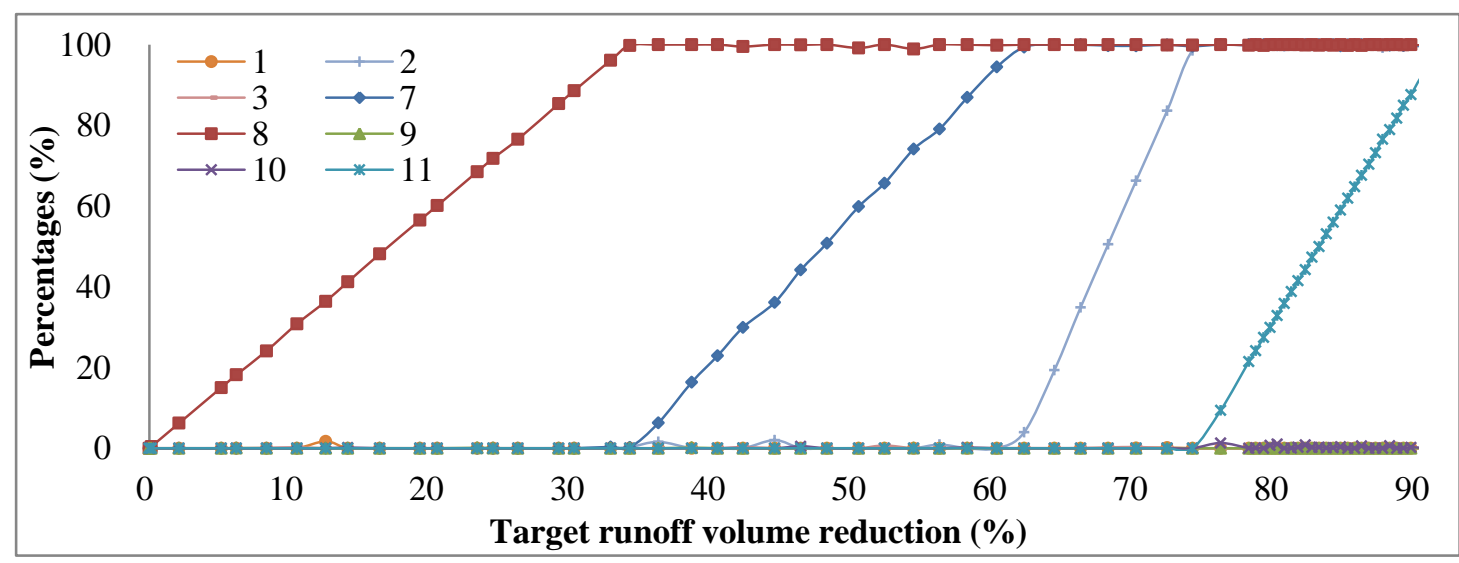

(b) Low density residential with soil group $\mathrm{C}$ 


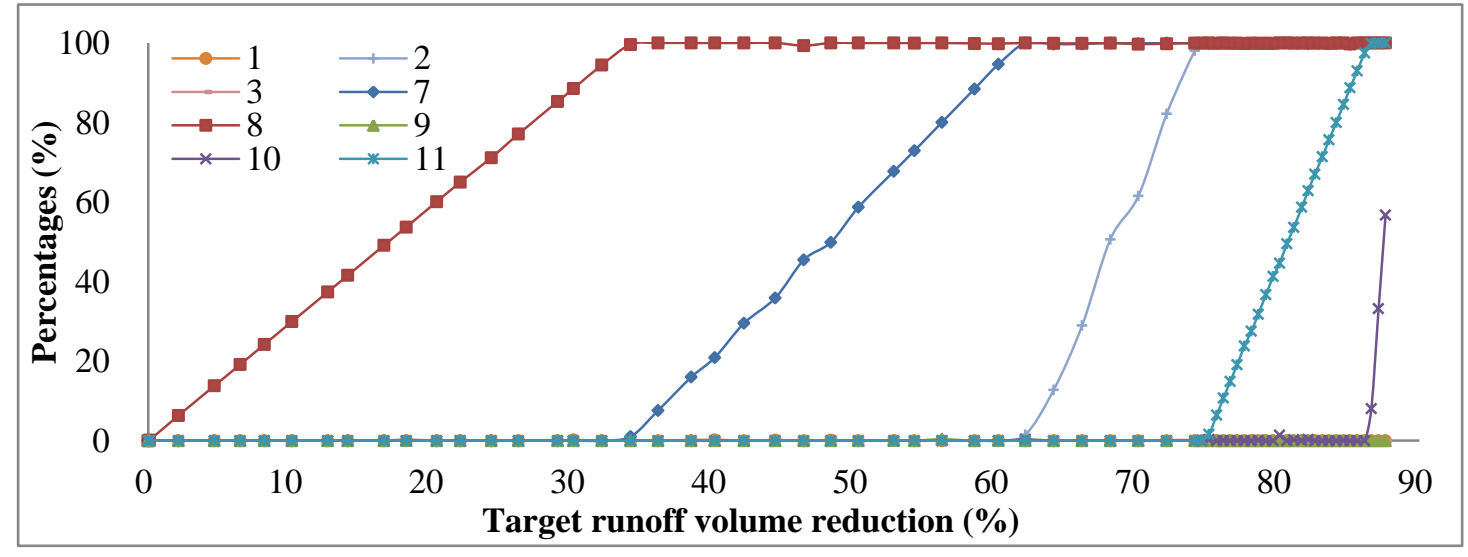

(c) Industrial with soil group D

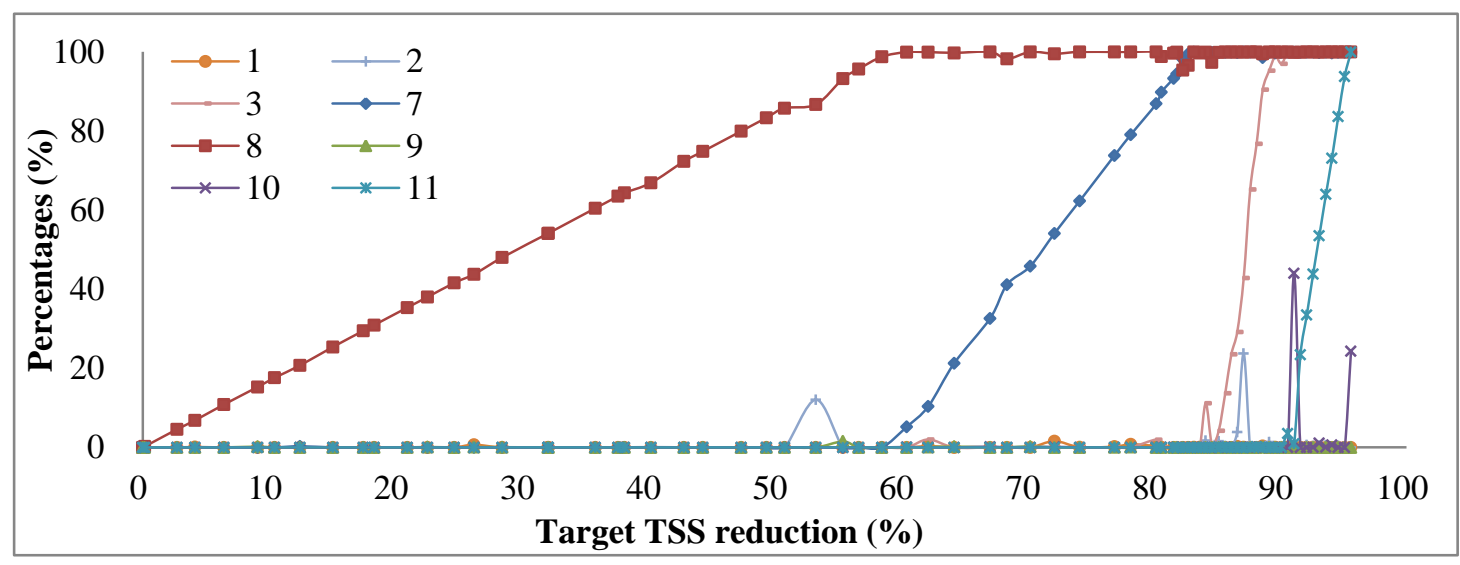

(d) High density residential with soil group D

Figure 5. Examples of detailed Pareto solutions for various percentages of implementing BMPs and LID practices in HRU scale areas. Practices represented were 1-retention pond, 2-detention basin, 3-wetland basin, 7-grassed swale, 8-grass strip, 9-wetland channel, 10-bioretention system, and 11-porous pavement. The most cost-efficient BMPs/LID practices were picked up one by one during the optimization process. Runoff volume reduction and TSS reduction were target reductions.

\subsection{Watershed scale optimization results}

Watershed scale optimization results for all scenarios are shown in Figure 6, in which light grey circles are all results during optimization and dark grey circles constitute the Pareto optimal fronts. The $\mathrm{x}$-axis shows the costs in million dollars over a 20 year period, while the $y$-axis presents the effectiveness in percent reductions. The upper left fronts of optimization results are Pareto solutions that show the maximum environmental impacts with minimum cost of implementing BMPs and LID practices. 
A portion of left side plots were zoomed in and shown on the right side. Since plots were zoomed in at different scales to compare findings, the density of solution points differs among objective functions. All these Pareto solutions were the best solutions, and the objectives were conflicting - the improvement in hydrology/water quality would only be achieved with more expense to implement BMPs and LID practices. Each Pareto solution in Figure 6 was the optimal result for the whole watershed by combining 123 HRU scale allocations of BMPs and LID practices. The detailed optimal solution (in the format of Figure 5 in section 3.2) for implementing BMPs and LID practices at the watershed scale was not presented in the paper because of the complexity of each Pareto solution, which included 123 HRU scale optimal results.
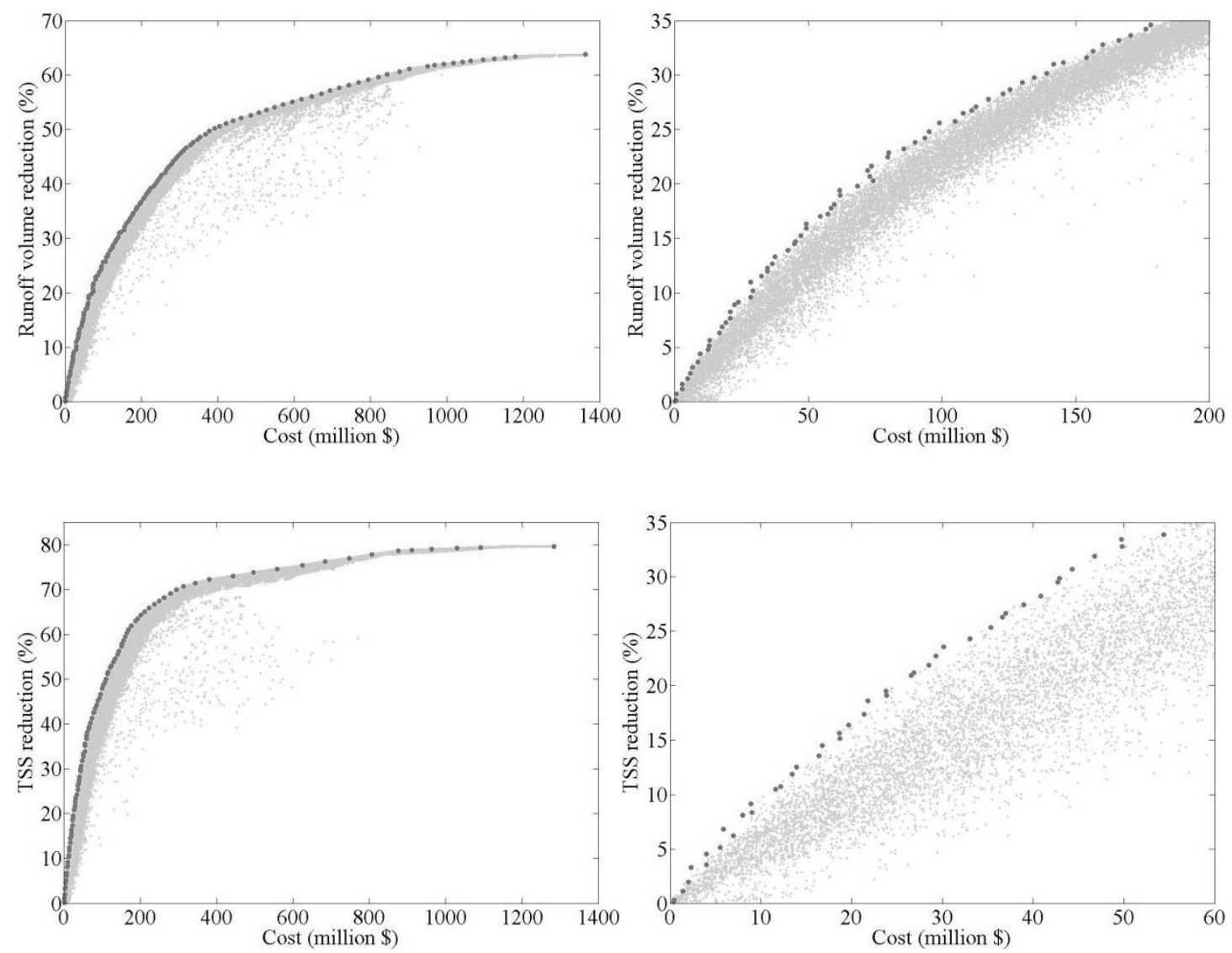

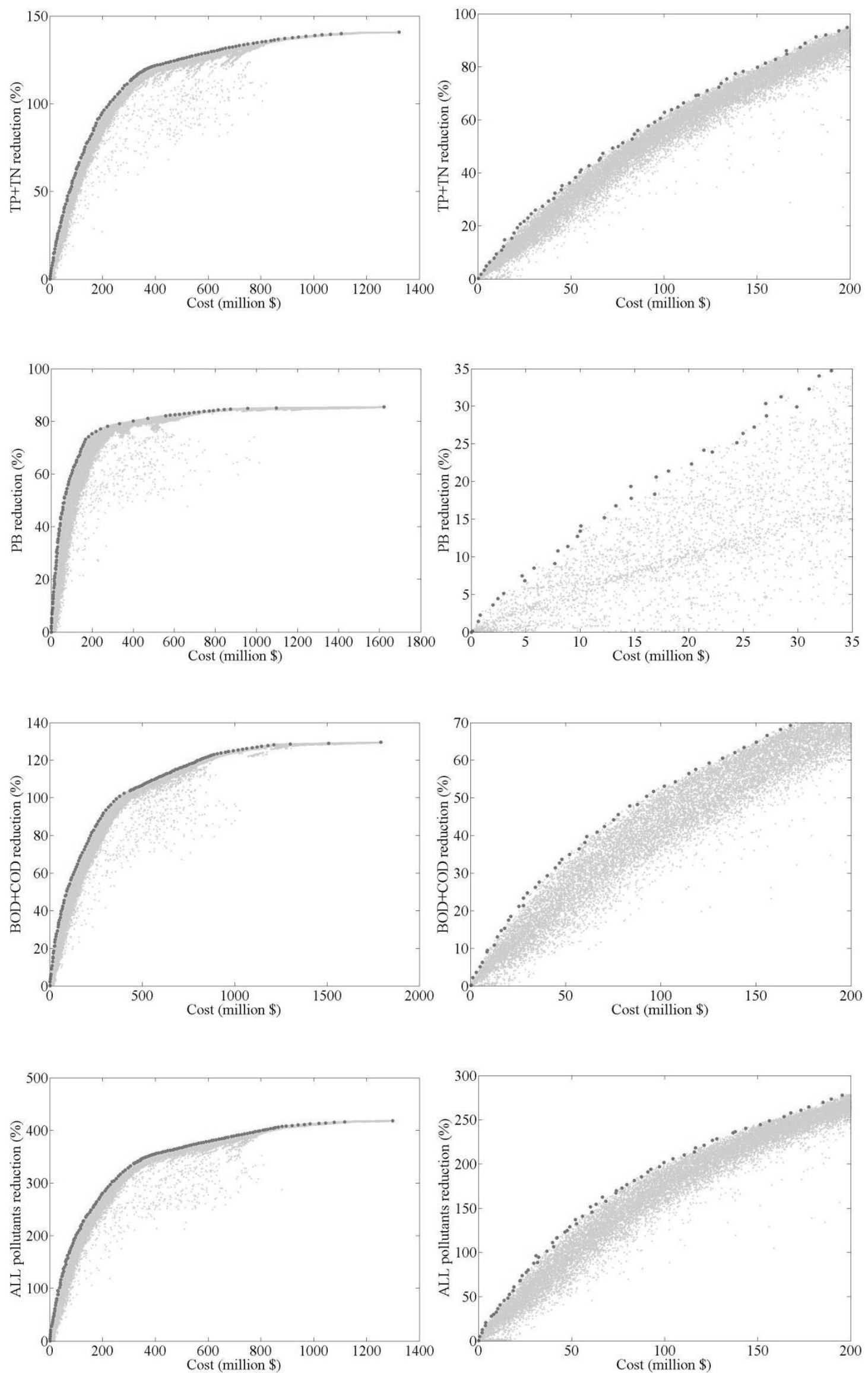
Figure 6. Watershed scale optimization results for all scenarios. Plots on the left side were zoomed in and shown as plots on the right side. Costs are total implementation and maintenance cost for a period of 20 years.

Pareto optimal fronts for all scenarios in Figure 6 indicate that by implementing more BMPs and LID practices, runoff volume and pollutant loads can be reduced further. For small total expenditures, additional expenditures to implement BMPs/LID practices greatly increased environmental impacts. However, beyond a given expenditure, spending more money did not result in substantial reductions of runoff volume and pollutant loads. Due to the treatment abilities of BMPs and LID practices, implementing more practices in series at the watershed scale would not necessarily result in significant further reductions in runoff volume and pollutant loads (Liu et al., 2015b). This resulted in less significant environmental impacts for additional spending beyond certain levels.

For the same cost (Figure 6), reductions in runoff volume were smaller than reductions in pollutant loads. For example, by spending 60 million dollars for a period of 20 years, runoff volume was reduced by $18 \%$, while TSS loads, average TP/TN loads, $\mathrm{Pb}$ loads, average BOD/COD loads, and the average of six pollutants loads were reduced by $38 \%, 22 \%, 49 \%, 19 \%$, and $25 \%$, respectively. This was expected because reduction of pollutant loads by implementing BMPs and LID practices was not only caused by reducing runoff volume, but also by decreasing pollutant concentrations.

\section{$\underline{4.4 \text { Comparison of optimization and random scenarios }}$}

Table 4 shows the comparison of hydrology and water quality impacts of optimization and random scenarios for the same BMP and LID practice expenditure. For the same expenditure, optimized implementation of BMPs and LID practices had 3.9 to 7.7 times as much reduction in runoff and pollutant loads as the random scenario. For example, by spending 47.7 million dollars for a period of 20 years, the random scenario only reduced runoff volume by $2.3 \%$, while the optimized scenario reduced runoff volume by $15.4 \%$. 
Table 5 shows the comparison of total cost of optimization and random scenarios to achieve the same hydrology and water quality impacts. To achieve the same runoff and pollutant load reductions, random scenarios cost 4.2 to 14.5 times as much as the optimized scenarios. For instance, to reduce runoff volume by $0.9 \%$, the optimized scenario only cost 1.8 million dollars over 20 years, while the random scenario cost 16.0 million dollars for a period of 20 years.

Figure 7 shows a map of optimization and random scenarios for an approximately 7 ha area in the study watershed. The optimization scenario was to reduce the maximum runoff volume with expenditure of 16.0 million dollars in the watershed over 20 years, while the random scenario was RS2 in Table 4. Both the optimization and random scenarios had the same expenditure. However, the optimization scenario reduced runoff volume more than the random scenario. The map shows the types and percentages of practices implemented in optimization and random scenarios were significantly different.

To optimally select and place BMPs and LID practices, the decision support tool can satisfy objectives of maximizing runoff volume/pollutant load reduction for a given budget or minimizing cost given a goal of runoff volume/pollutant load reduction. These results indicate the capability of the decision support tool to estimate tradeoffs among environmental impacts and economic considerations. The decision support tool is able to identify optimal solutions from a sizeable group of BMPs and LID practices with various cost efficiencies and levels of effectiveness in reducing runoff volume and pollutants for complex watersheds with intricate land use, soil, and other features.

For practical uses, the decision support tool could help decision makers optimally select and place BMPs and LID practices at watershed scales to attain maximum environmental impacts with minimum costs. Decision makers can choose the best solution from the alternative Pareto solutions by considering constraints in optimization problems based on additional criteria, such as limited budget resources and specific environmental goals. 
Table 4. Environmental impacts of optimization and random scenarios with the same budget (total cost for 20 years) for implementing BMPs and LID practices (Budget $A-\$ 47.7$ million, budget $B-\$ 16.0$ million)

\begin{tabular}{lllll}
\hline \multirow{2}{*}{ Runoff } & Budget & $\begin{array}{l}\text { Random } \\
\text { Reduction (\%) }\end{array}$ & $\begin{array}{l}\text { Optimized } \\
\text { Reduction (\%) }\end{array}$ & $\begin{array}{l}\text { Ratio of Optimized } \\
\text { to Random Reduction }\end{array}$ \\
\hline \multirow{2}{*}{ TN+TP } & A & 2.3 & 15.4 & 6.7 \\
& B & 0.9 & 5.8 & 6.4 \\
TSS & A & 9.1 & 35.8 & 3.9 \\
& B & 3.7 & 15.1 & 4.1 \\
Pb & A & 7.5 & 32.2 & 4.3 \\
& B & 3.1 & 14.6 & 4.7 \\
BOD+COD & A & 8.8 & 43.9 & 5.0 \\
& B & 3.6 & 19.7 & 5.5 \\
All pollutants & A & 4.6 & 33.1 & 7.2 \\
& A & 1.9 & 14.7 & 7.7 \\
\hline
\end{tabular}

Table 5. Total cost for 20 years of optimization and random scenarios with the same environmental impacts

(Environmental impact (EI) A: RS1 cost \$47.7 million; EI B: RS2 cost \$16.0 million)

\begin{tabular}{llll}
\hline & $\begin{array}{l}\text { Environmental } \\
\text { Impact (EI) }\end{array}$ & $\begin{array}{l}\text { Optimized Cost } \\
\text { (million \$) }\end{array}$ & $\begin{array}{l}\text { Ratio of Random to } \\
\text { Optimized Cost }\end{array}$ \\
\hline \multirow{2}{*}{ Runoff } & A & 5.9 & 8.1 \\
& B & 1.8 & 8.9 \\
TN+TP & A & 9.5 & 5.0 \\
& B & 3.8 & 4.2 \\
TSS & A & 5.7 & 8.4 \\
& B & 2.3 & 7.0 \\
Pb & A & 6.6 & 7.2 \\
& B & 2.0 & 8.0 \\
BOD+COD & A & 4.2 & 11.4 \\
\multirow{2}{*}{ All pollutants } & B & 1.1 & 14.5 \\
& A & 8.3 & 5.7 \\
\hline
\end{tabular}



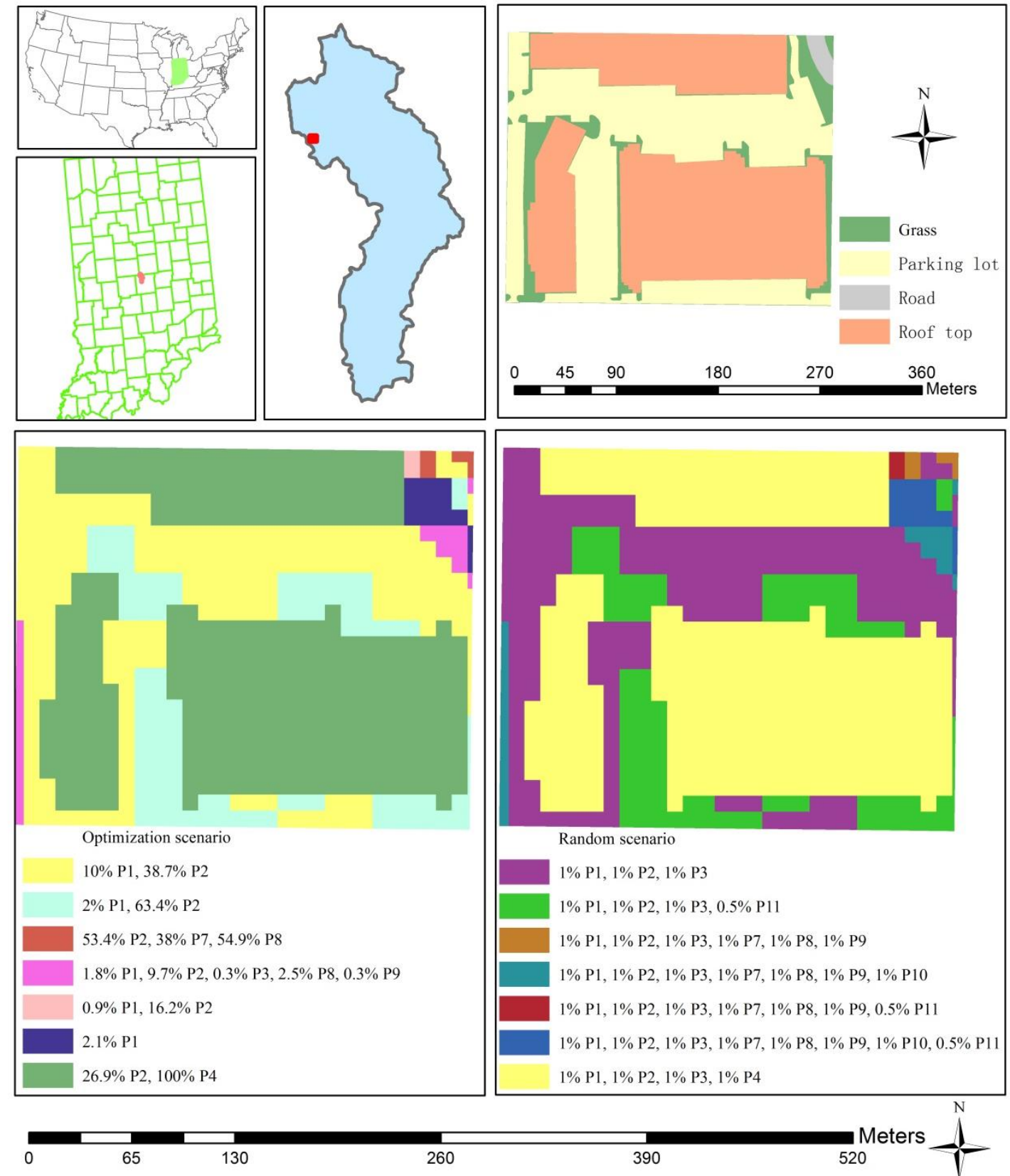

Figure 7. Map of optimization and random scenarios for an approximately 7 ha portion of study watershed results. Optimization scenario was to reduce the maximum runoff volume with expenditure of 16.0 million dollars over 20 years in the watershed. Random scenario was RS2 in Table 4. P1-retention pond, P2-detention basin, P3-wetland basin, P4-rain barrel/cistern, P7-grassed swale, P8-grass strip, P9-wetland channel, P10-bioretention system, and P11-porous pavement.

\subsection{Comparison with other models}

Other modelling frameworks have been developed to optimally select and place BMPs and LID practices in urban watersheds. The Stormwater Treatment and 
Analysis Integration (SUSTAIN) system (Shoemaker et al., 2009; Lee et al., 2012), which is a decision support system developed by U.S. Environmental Protection Agency, can be used to determine optimal cost, selection and placement of BMPs and LID practices. The decision support tool developed in this study differs from the SUSTAIN system. SUSTAIN uses the more complicated hydrologic/water quality SWMM5 (Storm Water Management Model, version 5) model and offers process-based estimation of practice effectiveness, which results in a more complicated process for preparing inputs/parameters and setting up the system, making it more difficult to use. The decision support tool developed in this study links optimization algorithms with a user friendly L-THIA-LID 2.1 model, which makes the decision support tool easier to use, such as a simpler data collection process for inputs/parameters that requires less expertise to operate. In the current SUSTAIN system, optimization algorithms include Scatter Search and Non-dominated Sorting Genetic Algorithm-II (NSGA-II); however, the newly developed decision support tool utilizes the AMALGAM method, which is a multi-algorithm optimization method that was found to be more efficient than single algorithm methods (Zhang et al., 2010). The decision support tool adopts a multilevel spatial optimization (MLSOPT) framework, which also reduces the computational complexity of optimization problems. SUSTAIN only conducts single level optimization, which increases optimization complexity and requires more computational time to obtain optimal results. The decision support tool can estimate environmental goals of reducing annual runoff volume and pollutant loads; while SUSTAIN evaluates factors such as peak discharge, annual volume, exceedance frequency, annual pollutant load/concentration, and maximum days average pollutant concentration. Both tools are able to estimate the cost of implementing BMPs and LID practices, although with different cost evaluation methods.

Another optimization framework, Storm Water Investment Strategy Evaluation (StormWISE) model (McGarity, 2012, 2013a, 2013b), was also developed to optimally implement BMPs and LID practices. The decision support tool developed in this study and the StormWISE model have some similarities as well as some 
dissimilarities. Both the decision support tool and the StormWISE model are implemented by running a daily simulation model using the curve number method; the decision support tool uses the L-THIA-LID 2.1 model, while StormWISE uses the generalized watershed loading function (GWLF) model. Both of the tools utilize two-level optimization frameworks; in the decision support tool, the first level optimization is conducted at sub-area scales, which are the unique combinations of HRUs and suitable BMPs/LID practices; StormWISE obtains first level optimization results in sub-areas with the same drainage zone and land use; both of the tools conduct second level optimization at the watershed scale. In the first level optimization using the decision support tool, sample populations with various implementation percentages of practices in each sub-area were created by AMALGAM, and used as the input for the L-THIA-LID 2.1 model; the simulation model runs once for each sample population. In the first level optimization, StormWISE minimizes computation by generating benefit functions with each piecewise linear segment slope determined by the cost effectiveness of each practice. The results of StormWISE (McGarity, 2013b) demonstrated a similar trend to the outputs of the first level optimization in this study (Figure 4), which showed piecewise linear plots. StormWISE utilizes a computationally efficient linear program to solve the second level optimization based on the first level piecewise linear functions; the decision support tool conducts second level optimization with AMALGAM using the look-up table created in the first level optimization.

Nevertheless, whether the optimization approach of StormWISE can be a substitution for the more computationally intense approach used in the decision support tool needs to be explored in future studies for several reasons. For one, not all BMPs/LID practices remained at $100 \%$ implementation after reaching the highest percentage (Figure 5); second, to use the StormWISE framework in the decision support tool proposed in this paper, the benefit function of each BMP/LID practice would be unique for HRU, runoff, pollutants, and weather, and therefore would need to be generated for each application of the tool to a new location, which may increase the complexity and time required. After determining whether the first level 
optimization results are truly linear using the decision support tool, the possibility of using linear programming instead of AMALGAM in the second level optimization could be explored. Further, the optimization framework in the decision support tool could be combined with more complex simulation models, which the optimization approach of StormWISE may not be able to accommodate. More detailed comparison of the decision support tool optimization methods and results with SUSTAIN model optimization approaches and findings could also be explored.

\section{Conclusions}

A decision support tool, which linked the L-THIA-LID 2.1 model with AMALGAM using the MLSOPT framework, was developed to optimally select and place BMPs and LID practices in various watersheds. In the decision support tool, the L-THIA-LID 2.1 model is the hydrologic/water quality simulation model, AMALGAM contains optimization algorithms, and the MLSOPT framework is used to reduce the complexity of optimization. The decision support tool was applied in Crooked Creek watershed, an urbanized watershed in Indiana, USA, to optimally implement BMPs and LID practices.

HRU scale optimization results indicated that for sites with different features, the optimal BMPs/LID practice solutions to attain the same environmental goals would differ; for the same combination of HRU and suitable practices, the favorable percentages and combinations of practices could be significantly different for various runoff volume/pollutant load reduction objectives. For higher expenditures, the implementation percentages and types of favored practices tended to increase relative to those for lower expenditures. These results demonstrated the need to optimally select and place practices with lower cost per unit runoff volume/pollutant load reduction.

The watershed scale selection and placement of BMPs and LID practices were optimized for the study watershed. When few practices were implemented in the watershed, increased practice expenditures greatly reduced runoff volume and pollutant loads. However, beyond a certain level of expenditure, spending more 
money did not always result in obvious reductions of runoff volume and pollutant loads. For the same BMP and LID practice expenditure, percent reductions in runoff volume were smaller than percent reductions in pollutant loads.

Optimization results were compared with the findings for random placement of BMPs and LID practices. The results showed that for the same BMP and LID practice expenditure, optimized implementation of BMPs/LID practices had 3.9 to 7.7 times as much reduction in runoff and pollutant loads as the random scenario. To achieve the same level of runoff and pollutant load reduction, random scenarios cost 4.2 to 14.5 times as much as the optimized scenarios.

To optimally select and place BMPs and LID practices at watershed scales, the decision support tool was capable of maximizing the reduction of runoff volume/pollutant loads for a given budget or minimizing cost given a runoff or pollutant load reduction goal. The decision support tool, which can be applied in various areas, can support decision makers in optimally selecting and placing BMPs and LID practices to obtain maximum environmental benefits with minimum costs.

Future studies could be done to compare the differences of solutions to minimize one pollutant and multiple pollutants, to compare the decision support tool methods and results with those of other tools that can optimally select and place BMPs and LID practices at watershed scales in urban areas, such as the System for Urban Stormwater Treatment and Analysis Integration (SUSTAIN) Model (Shoemaker et al., 2009), and Storm Water Investment Strategy Evaluation (StormWISE) (McGarity, 2012, 2013a, 2013b). More research could be conducted to explore the possibility and results of combining more detailed simulation models with the optimization framework in the decision support tool. Whether the linear behavior in first level optimization would occur if SWMM were used in EPA's SUSTAIN optimization framework could also be analyzed.

\section{Acknowledgments}

The data for this paper is available at National Climatic Data Center (http://www.ncdc.noaa.gov), United States Geological Survey (http://www.usgs.gov/), 
International Stormwater BMP Database (http://www.bmpdatabase.org/), IndianaMap Layer Gallery (http://maps.indiana.edu/layerGallery.html), and Soil Survey Geographic (SSURGO) database (http://www.nrcs.usda.gov/). I thank Dr. Jasper Vrugt for kindly sharing MATLAB codes for AMALGAM.

\section{References}

Ahiablame, L.M., Engel, B.A. Chaubey, I., 2012. Representation and evaluation of low impact development practices with L-THIA-LID: An example for site planning. Environ. Pollut. 1(2), doi:10.5539/ep.v1n2p1.

Ahiablame, L.M., Engel, B.A., Chaubey, I., 2013. Effectiveness of low impact development practices in two urbanized watersheds: Retrofitting with rain barrel/cistern and porous pavement. J. Environ. Manage. 119, 151-161, doi: 10.1016/j.jenvman.2013.01.019.

Arabi, M., Govindaraju, R.S., Hantush, M.M., 2006. Cost-effective allocation of watershed management practices using a genetic algorithm. Water Resour. Res. 42, W10429, doi:10.1029/2006WR004931.

Bhaduri, B., Grove, M., Lowry, C., Harbor, J., 1997. Assessing the Long term Hydrological Impact of Land-use Change: Cuppy-McClure Watershed, Indiana. J. Am. Water Works Ass. 89 (11): 94-106.

Choi, W., 2007. Estimating Land-use Change Impacts on Direct Runoff and Non-point Source Pollutant Loads in the Richland Creek Basin (Illinois, USA) by Applying the L-THIA Model. J. Spat. Hydrol. 7 (1): 47-65.

Cibin, R., and Chaubey I., 2015. A computationally efficient approach for watershed scale spatial optimization. Environ. Modell. Softw. 66, 1-11.

Damodaram, C., Giacomoni, M.H., Khedun, C.P., Holmes, H., Ryan, A., Saour, W., Zechman, E.M., 2010. Simulation of Combined Best Management Practices and Low 
Impact Development for Sustainable Stormwater Management1. J. Am. Water Resour. As. 46(5), 907-918.

Davis, A.Y., Pijanowski, B.C., Robinson, K., Engel, B.A., 2010. The Environmental and Economic Costs of Sprawling Parking Lots in the United States. Land use Policy 27 (2): 255-61.

Deb, K., Pratap, A., Agarwal, S., Meyarivan, T., 2002. A fast and elitist multiobjective genetic algorithm: NSGA-II. IEEE Trans. Evol. Comp. 6(2): 182-197.

Dietz, M.E., 2007. Low impact development practices: A review of current research and recommendations for future directions. Water Air Soil Poll. 186(1-4), 351-363.

Engel, B.A., Choi, J.Y., Harbor, J., Pandey, S., 2003. Web-based DSS for hydrologic impact evaluation of small watershed land use changes. Comput. Electron. Agr. 39:241-249.

Gilroy, K.L., McCuen, R.H., 2009. Spatio-temporal effects of low impact development practices. J. Hydrol. 367(3), 228-236.

Gitau, M.W., Veith, T.L., Gburek, W.J., 2004. Farm-level optimization of BMP placement for cost-effective pollution reduction. T. ASAE 47(6), 1923-1931.

Haario H., Saksman, E., Tamminen, J., 2001. An adaptive metropolis algorithm. Bernoulli, 7(2): 223-242.

Harbor, J., 1994. A practical method for estimating the impact of land use change on surface runoff, groundwater recharge and wetland hydrology. J. Am. Plann. Assoc. 60, 91-104, doi:10.1080/01944369408975555.

Joseph, J.F., Guillaume, J.H.A., 2013. Using a parallelized MCMC algorithm in R to identify appropriate likelihood functions for SWAT. Environ. Model. Softw. 46, 292-298. http://dx.doi.org/10.1016/j.envsoft.2013.03.012. 
Kennedy J., Eberhart, R.C., 2001. Swarm Intelligence. Morgan Kaufmann, San Mateo.

Lautenbach, S., Volk, M., Strauch, M., Whittaker, G., Seppelt, R., 2013. Optimization based trade-off analysis of biodiesel crop production for managing an agricultural catchment. Environ. Model. Softw. 48, 98-112.

Lee, J. G., Selvakumar, A., Alvi, K., Riverson, J., Zhen, J. X., Shoemaker, L., Lai, F. H., 2012. A watershed-scale design optimization model for stormwater best management practices. Environ. Model. Softw. 37, 6-18.

Liu, J., Zhu, A., Liu, Y., Zhu, T., Qin, C. Z., 2014. A layered approach to parallel computing for spatially distributed hydrological modeling. Environ. Model. Softw. 51, 221-227.

Liu, Y., Ahiablame, L.M., Bralts, V.F., Engel, B.A., 2015a. Enhancing a rainfall-runoff model to assess the impacts of BMPs and LID practices on storm runoff. J. Environ. Manage. 147, 12-23. DOI: 10.1016/j.jenvman.2014.09.005.

Liu, Y., Bralts, V.F., Engel, B.A., 2015b. Evaluating the effectiveness of management practices on hydrology and water quality at watershed scale with a rainfall-runoff model. Sci. Total Environ 511, 298-308. doi:10.1016/j.scitotenv.2014.12.077.

Maringanti, C., Chaubey, I., Popp, J., 2009. Development of a multiobjective optimization tool for the selection and placement of best management practices for nonpoint source pollution control. Water Resour. Res. 45, W06406, doi:10.1029/2008WR007094.

Maringanti, C., Chaubey, I., Arabi, M., Engel, B.A., 2011. Application of a multi-objective optimization method to provide least cost alternatives for NPS pollution control. Environ. Manage. DOI:10.1007/s00267-011-9696-2. 
McGarity, A.E., 2012. Storm-Water Investment Strategy Evaluation Model for Impaired Urban Watersheds. J. Water Resour. Plann. Manage. 138(2), 111-124.

McGarity, A.E., 2013a. Optimization for Urban Watershed Management: Stormwater Runoff and Nonpoint Pollution Control. Chapter 8 in Water Resources Systems Analysis through Case Studies, ed. By David W. Watkins, Jr., American Society of Civil Engineers.

McGarity, A.E., 2013b. Watershed Systems Analysis for Urban Stormwater Management to Achieve Water Quality Goals. J. Water Resour. Plann. Manage. 139(5), $464-477$

Pandey, S., Gunn, R., Lim, K.J., Engel, B.A., Harbor, J., 2000. Developing a Web-enabled Tool to Assess Long-term Hydrologic Impacts of Landuse Change: Information Technology Issues and a Case Study. URISA-WASHINGTON DC 12(4), $5-22$.

Prince George's County, Department of Environmental Resources, 1999. Low-Impact Development Design Strategies: An Integrated Design Approach. Department of Environmental Resources, Programs and Planning Division.

Rao, P., 2005. A parallel RMA2 model for simulating large-scale free surface flows. Environ. Model. Softw. 20(1), 47-53.

Rodriguez, H.G., Popp, J., Maringanti, C., Chaubey, I., 2011. Selection and placement of best management practices used to reduce water quality degradation in Lincoln Lake watershed. Water Resour. Res. 47, W01507, doi: 10.1029/2009WR008549.

Rouholahnejad, E., Abbaspour, K.C., Vejdani, M., Srinivasan, R., Schulin, R., Lehman, A., 2012. A parallelization framework for calibration of hydrological models. Environ. Model. Softw. 31, 28-36. 
Shoemaker. L., Riverson Jr,, J., Alvi, K., Zhen, J.X., Paul, S., Rafi, T., 2009. SUSTAIN-A Framework for Placement of Best Management Practices in Urban Watersheds to Protect Water Quality. Fairfax, VA.

Storn R., Price, K., 1997. Differential evolution — a simple and efficient heuristic for global optimization over continuous spaces. J. of Global Optim. 11: 341-359.

Sudheer, K.P., Lakshmi, G., Chaubey, I., 2011. Application of a pseudo-simulator to evaluate the sensitivity of parameters in complex watershed models. Environ. Model. Softw. 26, 135-143.

Tang, Z., Engel, B.A., Pijanowski, B.C., Lim, K.J., 2005. Forecasting Land Use Change and Its Environmental Impact at a Watershed Scale. J. Environ. Manage. 76 (1): $35-45$.

Tedesco, L.P., Hoffmann, J., Bihl, L., Hall, B.E., Barr, R.C., Stouder, M., 2011. Upper White River Watershed Regional Watershed Assessment and Planning Report.

The LIDC (Low Impact Development Center, Inc.), GeoSyntec Consultants, University of Florida, and Oregon State University, 2006. Evaluation of best management practices for highway runoff control. Transportation Research Board, National Research Council.

USEPA (U.S. Environmental Protection Agency), 2004. Stormwater Best Management Practice Design Guide: Volume 2. EPA/600/R-04/121A, U.S. Environmental Protection Agency, Office of Research and Development, Washington, DC.

USEPA (US Environmental Protection Agency), 2008. Reducing Stormwater Costs through Low Impact Development (LID) Strategies and Practices. EPA 841-F-07-006, Nonpoint Source Control Branch, Washington, D.C.

Vrugt, J.A., Robinson, B.A., 2007. Improved evolutionary optimization from 
genetically adaptive multi-method search. Proc. Nat. Acad. Sci. 104: 708-711.

Yalew, S., van Griensven, A., Ray, N., Kokoszkiewicz, L., Betrie, G.D., 2013.

Distributed computation of large scale SWAT models on the grid. Environ. Model.

Softw. 41, 223-230. http://dx.doi.org/10.1016/j.envsoft.2012.08.002.

Zhang, X., Beeson, P., Link, R., Manowitz, D., Izaurralde, R.C., Sadeghi, A., Thomson, A.M., Sahajpal, R., Srinivasan, R., Arnold, J.G., 2013. Efficient multiobjective calibration of a computationally intensive hydrologic model with parallel computing software in Python. Environ. Model. Softw. 46, 208-218.

Zhang, X., Izaurralde, R.C., Manowitz, D., West, T.O., Post, W.M., Thomson, A.M., Williams, J.R., 2010. An integrative modeling framework to evaluate the productivity and sustainability of biofuel crop production systems, GCB Bioenergy, 2(5), 258-277.

\section{Appendix}

Table A.1 Irreducible concentration values (www.bmpdatabase.org). Missing values are due to lack of data, and assumed with no pollutant concentration reductions. Values could be updated when more data are available.

\begin{tabular}{lllllll}
\hline & $\mathrm{TN}$ & $\mathrm{TP}$ & $\mathrm{TSS}$ & $\mathrm{Pb}$ & $\mathrm{BOD}$ & $\mathrm{COD}$ \\
& $(\mathrm{mg} / \mathrm{L})$ & $(\mathrm{mg} / \mathrm{L})$ & $(\mathrm{mg} / \mathrm{L})$ & $(\mathrm{ug} / \mathrm{L})$ & $(\mathrm{mg} / \mathrm{L})$ & $(\mathrm{mg} / \mathrm{L})$ \\
\hline Retention pond & 1.28 & 0.13 & 13.50 & 2.75 & $\mathrm{~N} / \mathrm{A}$ & N/A \\
Detention basin & N/A & 0.22 & 24.20 & 3.09 & N/A & N/A \\
Wetland basin & N/A & 0.08 & 9.06 & 1.21 & N/A & N/A \\
Rain barrel/Cistern & N/A & N/A & N/A & N/A & N/A & N/A \\
Permeable patio & N/A & N/A & N/A & N/A & N/A & N/A \\
Green roof & N/A & N/A & N/A & N/A & N/A & N/A \\
Grassed swale & 0.71 & N/A & 13.60 & 2.02 & N/A & N/A \\
Grass strip & 1.13 & N/A & 19.10 & 1.96 & N/A & N/A \\
Wetland channel & 1.33 & 0.14 & 14.40 & 2.49 & N/A & N/A \\
\hline
\end{tabular}




\begin{tabular}{lcccccc}
\hline Bioretention system & 0.90 & 0.09 & 8.29 & 2.52 & N/A & N/A \\
Porous pavement & N/A & 0.09 & 13.30 & 1.86 & N/A & N/A \\
\hline
\end{tabular}

Table A.2 Ratio of outflow concentration to inflow concentration values (www.bmpdatabase.org). Values could be updated when more data are available.

\begin{tabular}{lcccccc}
\hline & $\mathrm{TN}$ & $\mathrm{TP}$ & $\mathrm{TSS}$ & $\mathrm{Pb}$ & $\mathrm{BOD}$ & $\mathrm{COD}$ \\
\hline Retention pond & 0.70 & 0.43 & 0.19 & 0.32 & 1.00 & 1.00 \\
Detention basin & 1.00 & 0.78 & 0.36 & 0.51 & 1.00 & 1.00 \\
Wetland basin & 1.00 & 0.65 & 0.45 & 0.60 & 1.00 & 1.00 \\
Rain barrel/Cistern & 1.00 & 1.00 & 1.00 & 1.00 & 1.00 & 1.00 \\
Permeable patio & 1.00 & 1.00 & 1.00 & 1.00 & 1.00 & 1.00 \\
Green roof & 1.00 & 1.00 & 1.00 & 1.00 & 1.00 & 1.00 \\
Grassed swale & 0.96 & 1.00 & 0.63 & 0.52 & 1.00 & 1.00 \\
Grass strip & 0.84 & 1.00 & 0.44 & 0.22 & 1.00 & 1.00 \\
Wetland channel & 0.84 & 0.93 & 0.72 & 0.85 & 1.00 & 1.00 \\
Bioretention system & 1.00 & 1.00 & 1.00 & 1.00 & 1.00 & 1.00 \\
Porous pavement & 0.72 & 0.79 & 0.22 & 0.67 & 1.00 & 1.00 \\
Retention pond & 1.00 & 0.57 & 0.20 & 0.43 & 1.00 & 1.00 \\
\hline
\end{tabular}

